\title{
Medicines Australia Code of Conduct: breaches 2016-17
}

Keywords

Medicines Australia, codes of conduct

Aust Prescr 2017:40:238

https://doi.org.au/10.18773/ austprescr.2017.072
The Medicines Australia Code of Conduct guides the promotion of prescription products by pharmaceutical companies.' Each year Medicines Australia publishes a report, from its Code of Conduct Committee, which details all the complaints that have been received about advertising and other promotional activities. In 2016-17 only five complaints were dealt with by the Code of Conduct Committee and in the April-June 2017 quarter there were no complaints at all.
The Table shows the one complaint where at least one breach was identified, and more details can be found in the full report. ${ }^{2}$ The complaints were dealt with under the current (18th) edition of the Code of Conduct. ${ }^{1}$

Table Breaches of the Code of Conduct July 2016 - June 2017

\begin{tabular}{llll}
\hline Company & Brand (generic) name & Material or activity & Sanction \\
\hline Sanofi Genzyme & $\begin{array}{l}\text { Aubagio and Lemtrada } \\
\text { (teriflunomide and } \\
\text { alemtuzumab) }\end{array}$ & Misleading advertising & $\$ 50$ 000 fine, material \\
& & withdrawn \\
\hline
\end{tabular}

\section{REFERENCES}

1. Medicines Australia. Code of Conduct. 18th ed. 2015. https://medicinesaustralia.com.au/code-of-conduct/ code-of-conduct-current-edition [cited 2017 Nov 1]
2. Medicines Australia. Code of Conduct Annual Report 2016-2017. https://medicinesaustralia.com.au/codeof-conduct/code-of-conduct-reports/annual-reports [cited 2017 Nov 1] 